\title{
Tourism as an agent of reinvention for European equestrian intangible heritages
}

The case of three great public Classical Riding Schools

Le tourisme, agent de réinvention des patrimoines immatériels équestres

européens. Le cas de trois grandes écoles publiques d'équitation de tradition

Sylvine Pickel-Chevalier

\section{OpenEdition}

Journals

Electronic version

URL: http://journals.openedition.org/tourisme/3019

DOI: $10.4000 /$ tourisme.3019

ISSN: 2492-7503

\section{Publisher}

Éditions touristiques européennes

\section{Electronic reference}

Sylvine Pickel-Chevalier, "Tourism as an agent of reinvention for European equestrian intangible heritages", Mondes du Tourisme [Online], 18 | 2020, Online since 01 March 2021, connection on 15 March 2021. URL: http://journals.openedition.org/tourisme/3019; DOI: https://doi.org/10.4000/ tourisme.3019

This text was automatically generated on 15 March 2021.

\section{$(1) \Theta$}

Mondes du tourisme est mis à disposition selon les termes de la licence Creative Commons Attribution - Pas d'Utilisation Commerciale - Pas de Modification 4.0 International. 


\title{
Tourism as an agent of reinvention for European equestrian intangible heritages
}

The case of three great public Classical Riding Schools

Le tourisme, agent de réinvention des patrimoines immatériels équestres

européens. Le cas de trois grandes écoles publiques d'équitation de tradition

\author{
Sylvine Pickel-Chevalier
}

1 Europe is a melting pot of equestrian traditions, combining national characteristics with a shared heritage (Digard, 2007). These are the heirs of royal horse-riding traditions which proliferated during the Renaissance, while earlier medieval equestrian techniques were becoming obsolete (Roche, 2008). This common origin today explains, in part, the connection between European equestrian traditions which, nevertheless, reveal national and regional characteristics. However, science and technical progress and associated socio-economic and societal changes weakened the long-standing role of horses in the $20^{\text {th }}$ century. Horses survived modernity by being re-codified as a source of sport and leisure in consumer society (Tourre-Malen, 2009). The redefinition of their use was accompanied by a profound change in the profiles of horse practitioners who were younger, more often female and coming from the upper and upper-middle classes (Adelman and Knijnik, 2013). Their expectations transgressed previous practices. The paradigm of initiatory education was followed by one of pleasure and emotion. Education therefore needed to adapt. Horse-riding was no longer a form of military instruction based on the ability to "manage". It was redefined as an inter- and intrapersonal self-development medium, boosted by a desire for social distinction and an emotional relationship with the animal (Pickel-Chevalier, 2017). Anyway, faced with such changes, the question of the survival of classical riding has arisen. Various Equestrian schools in Europe intend to maintain this tradition: the Spanish Riding School of Vienna, the Cadre Noir de Saumur, the Royal Andalusian School of Equestrian Art of Jerez and the Portuguese School of Equestrian Art of Lisbon. They aim to protect classical riding styles in their countries, by redefining them as (tangible and intangible) 
heritage, as illustrated by the registration on UNESCO's Representative List of the Intangible Cultural Heritage of Humanity, of the Equitation in the French tradition, represented by the Cadre Noir de Saumur (2011) and of the Classical horsemanship and the High School of the Spanish Riding School of Vienna (2015). To do so, they must also demonstrate their capacity to transmit and communicate this classical riding to a large community, combining horse specialists and the general public. In this context, the four schools have taken the initiative of associating the training of students with tourism activities.

The objective of my study is to investigate the capacity of these schools to conserve the intangible heritage of classical riding in modern society, through this double strategy of transmission that feeds itself, focusing particularly on: the Cadre Noir de Saumur that is part of the French Institute of Horses and Riding (IFCE); the Real Escuela Andaluza del Arte Ecuestre (FREAAE) of Jerez de la Frontera in Spain and the Escola Portuguesa de Arte Equestre (EPAE) of Lisbon in Portugal (see figure 1). In doing so, I will also question the construction of intangible heritage, including the (re)invention of traditions, and the role of tourism in this process.

Figure 1. Location of the three studied classical riding-schools

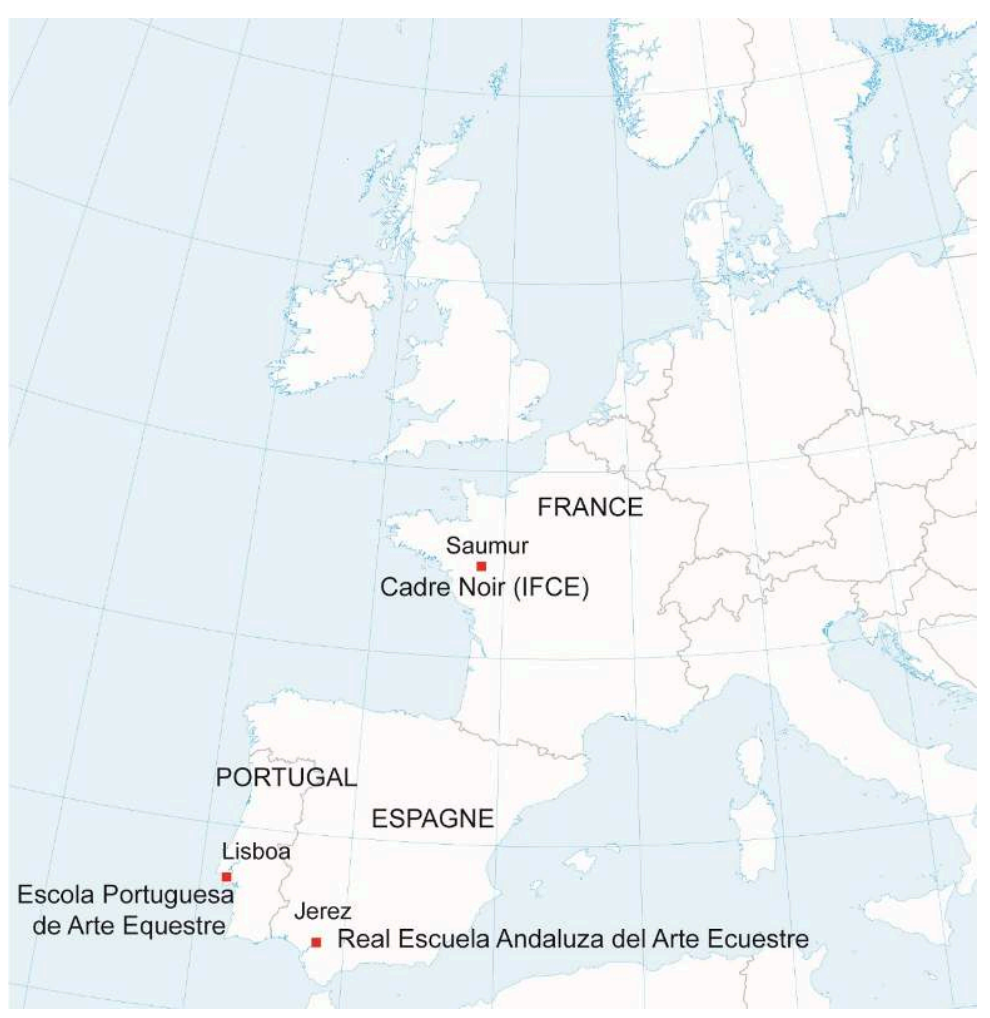

\section{Heritage, Tradition and Tourism}

From an institutional point of view, the Council of Europe defines cultural heritage as:

a group of resources inherited from the past which people identify, independently of ownership, as a reflection and expression of their constantly evolving values, beliefs, knowledge and traditions. It includes all aspects of the environment resulting from the interaction between people and places through time. ${ }^{1}$ 
Cultural heritage is acknowledged as less strictly inherited and more collectively constructed. Still, not everything can be classed as 'heritage': its status is the result of collective choices, contributing to the construction of memory through the recognition of common identity milestones (Babelon and Chastel, 1995; Heinich, 2009). As such, culture, heritage and identity are not passed on in an unchanging way from one generation to the next (Hitchcock, King and Parnwell, 2010). They are, on the contrary, 'constantly reinvented [...], reimagined [...] symbolically constructed and often contested' (Wood, 1997, p.8). They are political constructions of what is remembered, and, because of this, they can be in a constant state of evolution. Heritage thus comes from an 'ideological dimension of memory' (Lazzarotti, 2013, p.748). This happens on a global level since the creation, in 1972, of the UNESCO World Heritage program that was based on the principle of a combined aesthetic and monumental European heritage. Founded on a Western principle of linearity of time, this notion of heritage encourages a distancing of the past from the present, with a tendency to fix objects so as to better protect them and pass them on to future generations. This principle of sanctuarisation of memory complicates the relationships with living heritage, which induces a perpetuation of practices requiring their compliance with contemporary society. The creation of the UNESCO intangible heritage list in 2003 aimed to tackle this dilemma by taking the process further. It was defined as:

$$
\begin{aligned}
& \text { the practices, representations, expressions, knowledge, skills - as well as the } \\
& \text { instruments, objects, artifacts and cultural spaces associated therewith - that } \\
& \text { communities, groups and, in some cases, individuals recognize as part of their } \\
& \text { cultural heritage. This intangible cultural heritage, transmitted from generation to } \\
& \text { generation, is constantly recreated by communities and groups in response to their } \\
& \text { environment, their interaction with nature and their history, and provides them } \\
& \text { with a sense of identity and continuity, thus promoting respect for cultural } \\
& \text { diversity and human creativity. }
\end{aligned}
$$

5 The intangible heritage favoured the rising of the community concept. C. Bortolotto states:

the definition insists on the role of social actors ("communities, groups and, in some cases, individuals") in the heritage recognition, not only through historical ("transmitted from generation to generation") but also evolutive and procedural dimensions of this heritage ("constantly recreated"), on its identity function for the social actors, for whom this heritage create a "sense of identity" [...]. (2011, p.26)

6 As such, intangible heritage affords prime importance to social actors, regarded as the essential agents of transmission but also of recreation of the living heritage with which they identify (Tornator, 2019; Saupin, 2015). The challenge is therefore for them to succeed in combining conservation with adaptation to the perceived needs and wants of a constantly evolving society.

7 Tourism can be a vector of this symbiosis. As O. Lazzarotti emphases: 'Heritage and tourism are two phenomena of the same dynamic of memory production: they are coconstituted' (2011, p.72). This phenomenon comes from the fact that: 'Culture and heritage constitute vital resources for tourism development, and tourism in turn makes an important contribution to cultural development' (Richards, 2000, p.9). The touristification of heritage contributes to its revitalisation, through its redefinition (Hitchcock, King and Parnwell, 2010) within societies which build common identity markers, incorporating the invention of tradition. This latter concept, which must be distinguished from "custom", is defined by relative invariance: "The past, real or 
invented, to which they refer imposed fixed (normally formalized) practices, such as repetition" (Hobsbawm, 2012a, p.2). Traditions essentially emerged in the period of rapid transformation of European societies, between the end of the 19th and the beginning of the 20th centuries, in the context of the affirmation of nation-states. Aiming to participate in social cohesion and identity construction at different scales from membership of a group to a nation - they are linked to the recognition of a community, either real or artificial. Therefore, they can be official political constructions - by institutions - or more spontaneous social constructions - by groups which are not necessarily formally organised (Hobsbawm, 2012b). Traditions mirror the societies' relationships with their historicity, defined as a rebuilding of the past, through the prism of contemporary perceptions and future projections (Hartog, 2003).

Tourism can contribute to this collective identity construction by the enhancement of a chosen history, inducing a process of memory selection and cultural reinvention (Lazzarotti, 2011), coming from the social actors. These combine heritage and tourism agents - representatives of institutions and local authorities, site managers, tourism and heritage professionals - and the tourists themselves. By the visits they chose, they express their social support which is essential to the recognition of a heritage value that justifies its protection (Saupin, 2015).

\section{Methodology}

9 My epistemological position is structuralist constructivism, defined by Bourdieu (1987) as a double approach that takes into consideration objective structures independent of consciousness, on the one hand, and the will of agents and their socially constructed relations, on the other. I largely agree with Guy Di Méo's approach, which affirms the importance for social geography of managing to reconcile analysis of both the tangible and intangible. The study of physical, historical and social structures must be connected to the phenomenological relationships that populations have with them. He argues that "Social geography takes into account the different shapes of spatial structuration, but also the lived perceptions of the socialised human beings who produce them." (Di Meo, 2016, p.15). Following this methodology, I based my work on analysis of the structural changes within the three schools, affected by the evolution of global and national socio-historical context, as well as on interpretative relations of individuals to their schools. I consider that subjective perceptions contribute to the perpetual construction of places. This approach gives a fundamental role to the actors, their practices, and representations (Lussault, 2003, p.39).

10 Finally, my work is based on a multi-case-study methodology (Yin, 2018). My ambition is to use empirical evidence from the three different sites to compare their differences and similarities and to build a more holistic picture. This method provides access to data through a wide variety of tools, mixing secondary data with primary material that I collected and analysed myself. Therefore, my approach combines:

- an analysis of the literature allowing me to understand the characteristics of riding in each school and to compare the structural evolution of the three institutions;

- a study of the statistics relating to the socio-economic situation of the schools (annual activity reports, school enrolment, tourism statistics); 
- qualitative participant and non-participant observations conducted on the three sites to analyse their operating models in March 2019 (Lisbon); May and July 2019 (Saumur) and June 2019 (Jerez);

- qualitative semi-structured and individual interviews conducted between March 2019 and January 2020, with 48 people, including: 6 representatives from both local and national tourism or culture institutions; 7 management, as well as 5 from the tourism and marketing departments of the schools; the 4 chief squires ( 2 in Jerez); 11 squires; 9 grooms and 6 apprentice squires and students. Figure 2 presents the interviewees, the capital letters of their names, professional status, gender and dates of interviews.

Figure 2. Interview summary table

\begin{tabular}{|c|c|c|c|c|c|}
\hline & $\begin{array}{l}\text { Schools } \\
\text { referred to }\end{array}$ & Acronym & Role & Gender & Date \\
\hline 1 & Jerez & $\mathrm{JR}$ & FREAAE director & Male & June 2019 \\
\hline 2 & Jerez & $\mathrm{JG}$ & FREAAE Marketing director & Male & June 2019 \\
\hline 3 & Jerez & $\mathrm{AD}$ & FREAAE Founder & Male & June 2019 \\
\hline 4 & Jerez & $\mathrm{VC}$ & In charge of the sales department & Female & June 2019 \\
\hline 5 & Jerez & $\mathrm{JC}$ & Squire, training director (chief squire) & Male & June 2019 \\
\hline 6 & Jerez & NR & Squire, competition director (chief squire) & Male & June 2019 \\
\hline 7 & Jerez & FI & Squire & Male & June 2019 \\
\hline 8 & Jerez & BB & Squire & Female & June 2019 \\
\hline 9 & Jerez & $\mathrm{JJ}$ & Groom & Male & June 2019 \\
\hline 10 & Jerez & RM & Groom & Male & June 2019 \\
\hline 11 & Jerez & MSJ & FREAAE Documentation Centre director & Female & June 2019 \\
\hline 12 & Jerez & $\mathrm{Bl}$ & 4 th year student & Female & June 2019 \\
\hline 13 & Jerez & JTR & 3rd year student & Female & June 2019 \\
\hline 14 & Jerez & PS & 3rd year student & Male & June 2019 \\
\hline 15 & Saumur & JMM & President of the executive board of IFCE & Male & March 2019 \\
\hline 16 & Saumur & JRG & IFCE General director & Male & July 2019 \\
\hline 17 & Saumur & PT & Chief Squire & Male & June 2019 \\
\hline 18 & Saumur & JMP & IFCE Training Director & Male & April 2019 \\
\hline 19 & Saumur & FD & $\begin{array}{l}\text { In charge of the tourism department at } \\
\text { IFCE }\end{array}$ & Female & March 2019 \\
\hline
\end{tabular}




\begin{tabular}{|c|c|c|c|c|c|}
\hline 20 & Saumur & FM & Communication department, Cadre Noir & Female & January 2020 \\
\hline 21 & Saumur & GF & Squire & Male & June 2019 \\
\hline 22 & Saumur & NB & Squire & Women & June 2019 \\
\hline 23 & Saumur & JMPO & Squire & Male & June 2019 \\
\hline 24 & Saumur & PVL & Squire & Women & June 2019 \\
\hline 25 & Saumur & DG & Trainee-squire & Male & July 2019 \\
\hline 26 & Saumur & BP & Trainee-squire & Male & July 2019 \\
\hline 27 & Saumur & JoJ & $\begin{array}{l}\text { Chief Groom at the training and } \\
\text { competition stable }\end{array}$ & Male & July 2019 \\
\hline 28 & Saumur & ChL & Deputy groom, training stable & Female & July 2019 \\
\hline 29 & Saumur & PhP & Groom, prestige stable & Male & July 2019 \\
\hline 30 & Saumur & OP & Chief squire, groom & Male & July 2019 \\
\hline 31 & Saumur & SS & $\begin{array}{l}\text { Vice-President of Saumur agglomeration } \\
\text { in charge of tourism }\end{array}$ & Female & April 2019 \\
\hline 32 & Saumur & PL & $\begin{array}{l}\text { Director of political research, Ministry of } \\
\text { Culture }\end{array}$ & Male & July 2019 \\
\hline 33 & Saumur & PHD & Director of the military horse museum & Male & $\begin{array}{l}\text { December } \\
2019\end{array}$ \\
\hline 34 & Saumur & JMH & $\begin{array}{l}\text { Member of the } \\
\text { expert council at the Army Museum, } \\
\text { Invalides. }\end{array}$ & Male & January 2020 \\
\hline 35 & Lisbon & JPR & Chief Squire & Male & March 2019 \\
\hline 36 & Lisbon & DS & EPAE Director & Male & March 2019 \\
\hline 37 & Lisbon & $\mathrm{JQ}$ & Squire & Male & March 2019 \\
\hline 38 & Lisbon & RV & Squire & Male & Mars 2019 \\
\hline 39 & Lisbon & $\mathrm{CT}$ & Squire & Male & March 2019 \\
\hline 40 & Lisbon & JMD & Trainee-squire & Male & March 2019 \\
\hline 41 & Lisbon & MaR & Trainee-squire & Female & March 2019 \\
\hline 42 & Lisbon & TGB & Trainee-squire & Female & March 2019 \\
\hline 43 & Lisbon & NMD & Chief groom & Male & March 2019 \\
\hline
\end{tabular}




\begin{tabular}{|l|l|l|l|l|l|}
\hline 44 & Lisbon & CG & Groom & Male & March 2019 \\
\hline 45 & Lisbon & MR & Groom & Female & March 2019 \\
\hline 46 & Lisbon & MAB & Carriage Museum curator & Female & March 2019 \\
\hline 47 & Lisbon & CC & Queluz Palace curator & Female & March 2019 \\
\hline 48 & Lisbon & TA & Former EPAE director & Female & March 2019 \\
\hline
\end{tabular}

11 The interviews were recorded and later transcribed. Each interview lasted between 1 and 2 hours and was guided by open-ended questions. The objective was to understand the organisation of the schools, combining training and tourism activities, and, in particular, the role of tourism in the construction and transmission of the classical riding traditions. I prioritised a qualitative approach with those involved in this policy at different levels. This provides a profound understanding of the behaviour and social practices, but also the mental representations, of the actors I interviewed. The questions posed to the chief squires and the management/tourism representatives were focused especially on the definition and purpose of their school, its relation to equestrian heritage, the relationship between education and tourism, the schools' strengths and weaknesses, their vision of the future and plans for the schools. The questions posed to the squires, grooms and students covered their activities within the schools, their relationships with equine heritage, their feelings about the strengths and weaknesses of the school, and their upcoming projects. I used manual thematic content analysis (Paillé and Mucchielli, 2008) to identify patterns and themes in their responses.

12 The results allowed me to comprehend the heritagisation process ${ }^{3}$ of these riding traditions, and the role of the classical schools in the (re)invention of national traditions, whether associated or not with local breeds. With this understanding, I analysed the school's strategy for the transmission of their equestrian heritage, questioning particularly the role of tourism in the constant construction and passingon of a living heritage to a larger community.

\section{The classical riding schools and the heritagisation of horse-riding}

\section{From technical developments to the invention of equestrian traditions}

13 If traditions are largely invented, they usually find their legitimacy in history, while "attempt[ing] to establish continuity with a suitable historic past" (Hobsbawm, 2012a, p.1). They answer the need to create a sensation of stability, especially marked in a period of important changes and transformations, such as the $19^{\text {th }}$ century, and more especially the Belle Epoque, between 1870 and 1914 (Hobsbawm, 2012b). The heritagisation of the three examples of classical horse-riding studied seems to confirm the 'invention of traditions'-theory. They take their legitimacy from the filiation of the extended European history of equestrian art. Specifically, the so-called Academic riding 
has grown since the Renaissance in Europe, and continued its evolution over four centuries, mixing the conservation of customs and innovations, to answer new societal - and especially military - needs (Roche, 2008). However, they only entered a process of heritagisation when their utility became weakened. As such, because of the Muslim conquest, the Iberian Peninsula has been a melting pot of medieval European riding called the brida, where the riders are sat deep in the saddle, legs extended and leaning against the stirrup to absorb the violence of jousting - and Arab and Berber riding called the jinetta, where the rider is suspended with their legs bent and heels in contact with the horse's flanks (Digard, 2007). The desire to conceptualise this practice and art was born in Portugal, with a first major treaty being written by King Dom Duarte in 1434. Since then, theorisation continued to flourish in other countries, for example, in Italy (Grisone, 1550; Fiaschi, 1556), in France (la Broue, 1593) and in Spain (de Andrada, 1599). It continued in the $17^{\text {th }}$ century in France (Pluvinel, 1623), in the UK (Cavendish, 1657) and Portugal (Pacheco, 1670; Rego, 1679). Nonetheless, European equestrian art arguably reached its apotheosis in the $18^{\text {th }}$ century with La Guérinière editing School of Cavalry (1733) and de Andrade, who in 1790 published Light of the Liberal and Noble Art of the Cavalry - describing the daily work of the squires at the Picaria Real (Royal Manege), the equestrian academy founded by King Joao V in 1726. They both presented the techniques of equestrian art at its peak, characterised by the intensified quest for grace and aesthetics and aimed at the social representation of aristocracy (Roche, 2008).

However, advances in technology at the end of the $19^{\text {th }}$ century onwards gradually made the traditional uses of the horse increasingly obsolete. They owe their survival in industrialising society to a move into the sporting world, typically favouring English breeds (for races or show jumping). This evolution thus especially affected Portuguese and Spanish classical riding styles since they were deeply associated with the genetics of their national horses. The Spanish horse was created on the instructions of King Philip II who, in 1567, gave orders for a new breed to be developed which would fit an idealised horse model, combining both flexibility and docility. It was fashioned to meet the ideals of comfort and beauty built into the collective imagination: small head, black eyes, short ears, wide neck, with a long and full tail (Altamirano, 2007). The breed began to stabilise at the start of the $17^{\text {th }}$ century and received approval from the masters of horse-riding schools across Europe. The Andalusian horse is therefore, like most equine breeds, the result of research into crossbreeding to meet riders' needs but also for cultural representations. The Royal Portuguese horse - the Alter Real - was also created from the Iberian horse in the $18^{\text {th }}$ century. This is a unique lineage, the breeding of which started in 1748 on a royal stud farm founded in the village of Alter do Chão on the orders of King Joao $\mathrm{V}$ who wanted to strengthen the production of quality horses for both performances and for warfare.

By contrast, there is no national horse preference as such in France, as the National Studs, created under Colbert (1665), are more concerned by the quest for performance and modernity than by the promotion of a national symbol (Roche, 2011). Paradoxically, the non-construction of a unique genetic national heritage in France favoured the continuity of its equestrian custom through adaptation. As early as the $18^{\text {th }}$ century a division has emerged between the art of court riding, aimed at social representation, and the needs of the cavalry for simplified and more utilitarian techniques. To satisfy this requirement, Louis XV founded the "Ecole des ChevauLegers de la Garde" in Versailles (1744), then the Royal Military School of Paris in 1751 
with a military Manège. The chief squire Colonel d'Auvergne, by repositioning the horse in its martial utility role, is considered to be the father of military riding in France. Since then, French riding has become deeply associated with the cavalry, seeing the creation of several schools in line with various political regimes. A Carabinieri brigade was founded in Saumur in 1763 but disappeared in 1788, while the École Nationale des Troupes à Versailles opened in 1796. In 1809, Napoleon established the École Spéciale de Cavalerie in Saint-Germain, which was later disbanded in 1814. That same year, the School of Mounted Troop Training was re-established in Saumur, run by squires from the Manèges at Versailles, the Tuileries or Saint-Germain, with either civilian or military status. Disbanded in 1822, it re-opened in 1825 under the name of the Royal Cavalry School. The instructors were then known as the "Cadre", responsible for passing on the institution's equestrian doctrine. The school was a crucible, combining civilian and military cultures which were visible in the way they associated those practices necessary for war and the academic techniques required for demonstrations. In 1828 the first carousel was revealed, including jumps and pillar work as they were practiced at the Manège de Versailles. Although they were recodified as methods intended to test the skill of the military riders, they quickly became objects emphasising the image of the school in the eyes of the general public. In parallel, the military also quickly assimilated the sporting evolution of riding by participating in races from 1850, and then in riding competitions from 1874.

It was only after the French defeat of 1870 in the Franco-Prussian War, that the role of the Cavalry was widely questioned, and the need to redefine riding as an emblem, more than a main weapon, arose. As such, it was under the Third Republic that French republican symbols were developed through the invention of traditions (Hobsbawn, 2012b), and that this process of heritagisation started. From 1874 onwards, the Ecuyers of the Cadre du Manège were distinguished from the instructors by their black collars, instead of the traditional blue. This resulted in them being nicknamed the "Cadre Noir", which has officially appeared in books since $1896^{4}$. From then on, the "Cadre Noir" become the icon of the school and of the French riding tradition, exhibited in France during the Belle Epoque and then throughout Europe in the aftermath of the First World War. Their practices were identified as both a military and a republican French tradition. It was seen by Charles Péguy, who compares the teachers at the Jules Ferry schools to those in 1913: "Our young teachers were handsome as black Hussars. [...] [Their] civil uniform was as a military uniform even more strict, even more military, being a civil uniform. Something, I think, like the famous Cadre Noir de Saumur"5.

17 French riding started its heritagisation process as early as the end of the $19^{\text {th }}$ century when the Spanish and Portuguese equivalents had almost disappeared, at least from official institutions. Portuguese equestrian art lapsed with the closure of the Picaria Real in 1807 and with the scattering of the Alter Real breeding activities following the departure of the Royal Court to Brazil (Abrantes, 2014). Portuguese and Spanish equestrian arts would have to wait for the $20^{\text {th }}$ century to be reinvented as national traditions, through the (re)creation of classical public schools.

\section{The (re)birth of the classical riding schools in today's society} associated with a national breed. As such, the first step of their reinvention was their 
official recognition: in 1912 the studbook of the Pura Raza Española (PRE) was created, becoming the official direct descendant of the Andalusian horse. In Portugal, the fall of the monarchy in 1910 threw into doubt the future of Royal Alter breeding. After being passed successively from the ministry of finance to that of war, the stud farm was effectively abandoned due to lack of interest. The last two stallions were sold in 1938 to Doctor d'Andrade. It was only in 1942, when the Alter stud was handed over to the Ministry of Economic Affairs, that the government decide to revive the lineage, thanks notably to Andrade's stallions. The Lusitano horse studbook, to which the Alter belongs, was created in 1966.

Those actions favoured the creation of the genetic heritage of the national breeds but could not prevent the decline of traditional equestrian practices. Their rebirth, through their redefinition as a national tradition, was the work of a few enthusiasts. In Spain, it was especially due to Álvaro Domecq in Jerez. He explained:

Before its creation, Spanish horse riding was transmitted empirically, without any framework or theorisation. The quality was lost. I felt that we had to create an institution in order to conceptualise and transmit our associated equestrian culture to good breeders, to boost the development of both the horse and traditional Andalusian riding; so they are not lost... [interview, AD]

When in May 1973 he received the "Golden Horse" from the Ministry of Information and Tourism, along with the support of the town hall in Jerez, to reward his contribution to the art of bullfighting, he decided to create a show named "Cómo Bailan los Caballos Andaluces" combining classical Renaissance and doma vaquera riding inherited from corrida (bull-fighting on horseback). This show, to which the prince and future king of Spain - were invited, resulted in significant media coverage which enabled Domecq to announce the creation of his school, at the same time seeking national and local support. In 1976 the Ministry of Culture acquired the Palacio del Recreo de las Cadenas to set up the future school of Andalusian Equestrian Art. In 1982 the Patronage of the Andalusian School of Equestrian Arts was created, managed by Cadiz Council, which in 1990 joined the region of Andalusia. The objective was then to set up an "equestrian university" for post-high-school students. In 1983, the Ministry of Information and Tourism acquired control of both the school and the shows run by Domecq, who then became technical director of the institution. From 1984 these rights were transferred to the autonomous community of Andalusia which also purchased 35 Spanish horses and 19 historic horse-drawn carriages. In 1987, the King accepted the title of honorary president of the school, making it a Royal School. In order to simplify the legal running of the institution, in 2002 the Royal Patronage of the School was replaced by a public foundation combining tourist, educational and cultural activities under the protectorate of the Andalusian Cultural Council: the Fundación Real Escuela Andaluza del Arte Ecuestre (FREAAE). Its objectives are specifically to promote both Spanish horses and equestrian art, through the school and permanent exhibitions (Altamirano, 2007).

The history of the Jerez Escola is characterised by the transformation of a private creation into a public and royal school, which was the aim of its founder [interview, AD]. In Portugal, on the contrary, the revitalisation of equestrian riding was a national initiative, but supported by the involvement of four enthusiasts. In 1979, the Portuguese Ministry of Agriculture founded the Escola Portuguesa de Arte Equestre. However, it was not initially given any structure of its own. Its operation was therefore essentially based on the motivation of the squires, aiming to boost a Portuguese 
equestrian heritage that had lost its visibility. In this context of the reinvention of tradition, they chose the riding of de Andrade and la Picaria Real, the $18^{\text {th }}$ century being the period of apogee for Portuguese equestrian art. From 1984 onwards, the squires put on regular shows in the gardens of the baroque Palácio Real de Queluz, located $15 \mathrm{~km}$ from Lisbon. Its gardens were then outfitted with stables, allowing the transfer of the Portuguese school of equestrian arts in 1996. In 2007, a foundation was created combining the school and the Alter breeding centre. However, the model did not prove viable and so the Portuguese State then changed its strategy, in 2012, by uniting the equestrian arts school at the Parques de Sintra. This is a public organisation responsible for promoting, through its tourism and heritage, the Sintra National Park (listed by UNESCO World Heritage since 1995), the Queluz Palace and subsequently the Portuguese School of Equestrian Arts. The Alter Real horse breeding centre, with around 60 broodmares and 15 stallions, is under the responsibility of the Companhia das Lezírias public agricultural and forestry company.

Under the aegis of Sintra, the school saw its objectives redefined with a blend of perpetuation and development. As such, the chairman of the board of directors stated: "The mission of the EPAE is to preserve traditional Portuguese equestrian arts and to contribute to the improvement and promotion of the Portuguese horse from the Alter stud farm, by developing its riders' knowledge and by training and showing off its horses" (cited in Abrantes, 2014, p.8). In 2016, the school returned to Belém where the Picaria Real had been founded almost three centuries earlier, but not in the historical arena as that has since become a carriage museum. As shown, the Portuguese school has adapted to changing circumstances throughout its history.

Relatedly, the Cadre Noir de Saumur started its heritagisation as early as the end of the $19^{\text {th }}$ century, its evolution continued during the whole of the $20^{\text {th }}$ century. After the Second World War, horse-riding in France embarked on a process of social diffusion, which gave birth to new leisure-oriented disciplines and institutions. The Saumur Cavalry School reflects these changes. For example, its teaching roles were transferred to the civilian sector in 1969 when they were awarded to the National Riding Institute, created in 1968. In 1972, the National Riding School (ENE) was founded to replace the institute. It re-focussed as a training centre with the aim of preparing students for state diplomas as horse riding teachers, supporting high-level sport and contributing to the perpetuation of the French riding tradition. Placed under the auspices of the Ministry of Sports, it included the "Cadre Noir". The National Riding School then separated from the Cavalry School, even if several of its squires retained their military status and its chief squire remains an officer, all seconded by the Ministry of Defence.

The split between the civilian and military institution was spatialised by the geographic displacement of the ENE, which left the centre of Saumur in 1977. Far from damaging its reputation, this separation contributed to a strengthening of the heritage process for the Cadre Noir, which was then officially detached from its military functionality. In 1984, the Grand Manège with 1,689 seats opened to receive visitors to the weekly exhibitions and galas. It was therefore from this demilitarisation that its military legend was reinforced, and then crystallised in the adoption of its common name "Cadre Noir de Saumur" as a registered trademark in 1986. In 2010, the State merged the National Riding School and the National Stud Farms to create the French Institute of Horses and Riding (IFCE), with new missions which were (2019): to produce and transfer knowledge relating to horses and riding; to support horse riding and high- 
level sports; to ensure the traceability of equines; to enhance the tangible and intangible heritage of horses and riding.

In this context, the school had to strengthen its cultural role by officially defining the French equestrian art as an intangible heritage (Pickel-Chevalier, 2016). Indeed, the international growth of equestrian leisure and sporting activities simultaneously generates an interest in equestrian cultures, but also the risk 'of losing significant landmarks and the appropriation by the few controlling the commercial and sporting deviations' [interview, BM]. These two phenomena led to a need for identification and recognition. The squires had to define the philosophy of their practices, through a selection of memory processes. Their choice has focused on General L'Hotte, combining 'the ambition of the forward movement, which has to show itself constant' with 'the harmony of the movements which show the correct use of the aids, and the lightness which ensues from it' (quoted in Henry and Oussedik, 2014, p.78). Therefore, French equestrian riding was registered on UNESCO's Intangible Cultural Heritage list as: "Equitation in the French tradition is a school of horse riding that emphasizes harmonious relations between humans and horses. The fundamental horse-training principles and processes are guided by non-violence and a lack of constraint, blending human demands with respect for the horse's body and mood. [...]" ${ }^{\prime 6}$ As such, it corresponds to a "kind of ethics for the relationship between man and horse and the fairly balanced relationship between animal and man which deals with contemporary concerns with regard to the status of animals in society" [interview, PL].

The (re)invention of three equestrian traditions resulted from an institutionalisation of memory (Hobsbawn, 2012a). This recognition needs the identification of a "community" who identify with them. It is in this context that the three schools have, since their creation, associated a tourism offer with their teaching activities, and been appropriated as a national symbol by the general public.

\section{The role of tourism in the conservation of equestrian traditions}

\section{The touristification of riding schools}

27 At all three sites, the managers, as well as the squires and the grooms, see their institutions primarily as actual schools, while also being touristic places. "Beyond everything, we are a school: our first mission is education" claimed a squire at the Cadre Noir [interview, NB]. This point of view is shared by the chief squire who explains: "The Cadre Noir has always had the role of producing and transmitting knowledge; a role that satisfies the contemporary concerns of IFCE" [interview, PT]. In Jerez, the chief squire JC stated: "We are a school whose mission is to teach to the students to preserve the tradition" [interview].

However, the education program differs from one school to another, depending also on the institutions' resources. The Cadre Noir is the biggest - with 284 horses owned by the school -, with a significant offering combining professional sports training (BPJEPS, DESJEPS) and university courses (Bachelor with the University of Angers), as well as expert training. Thanks to this diversity, the Cadre Noir took in 117 students in 2018. The appeal of the diploma courses is notably due to their national recognition by the Ministries of Sports and Higher Education. The institution also has an important 
relationship with modern competitive sport, as illustrated by the team gold medal won in eventing by squire T. Vallette at the Rio 2016 Olympic Games.

In FREAAE, which has 134 stabled horses (84 owned by the school), the offer is also diversified but the capacity for student enrolment is smaller. It offers one- to four-year programmes in: horse-riding training, driving, tack/saddlery, horse care and for veterinary assistants. In 2018, its intake was 32 students. The school is penalised by the fact that its training is not recognised by the state. The new director aims to overcome this limitation. He explained: "Our aim is to create a partnership with the University of Cadiz, which has a campus in Jerez, especially as they are interested in our training model" [interview, JR]. In addition to its normal training, the school offers 1- to 2-week equestrian progress courses ( 75 trainees in 2018). The school is not excluded from competitions which are of interest to almost half the students and squires interviewed. Several top international dressage athletes have graduated from the school, such as Ignacio Rambla or Rafael Soto, a silver medallist at the 2004 Olympic Games.

Finally, the EPAE, which is the smallest institution - 65 horses - is not yet a fully independent school but is more akin to an equestrian academy where experienced riders train the new arrivals. "We operate using a principle of companionship", explains the chief squire [interview, JPR]. The new school director aims to overcome this challenge by providing the EPAE with a training school. He now wishes to redevelop the Queluz site to create a training centre in partnership with the veterinary school at Lisbon University. The goal is to offer a Vocational Degree course over one year aimed at young people who wish to start their dressage school business, but also a non-degree course for professionals wishing to improve their skills. Finally, the EPAE does not distance itself from competitive objectives. The school, too, has trained dressage champions, including Diego Duarte (2008 Olympic Games) and Gonçalo Carvalho (2012 Olympic Games).

31 As demonstrated, the three institutions see themselves primarily as "schools" even if some of them are foremost a conservatory of traditions, lacking as they do in official national recognition of this task. However, their existence depends, for economic and also socio-cultural reasons, on their tourisfication. This claim was made by the IFCE President of the Executive board: "Bringing the French riding tradition to life necessarily requires an audience, so tourism offers are essential to the Cadre Noir" [interview JMM] Likewise, one of the chief squires at FREAAE explained: "Tourism is a motor for the school. Exhibitions provide the opportunity to showcase the work of the squires and the students. It favours a better transmission" [interview NR]. In addition, a squire from EPAE admitted: "I prefer to work with people watching me than alone. It is part of our mission, to transmit our heritage. And I'm proud that tourists can come" [interview CT]. This indicates a need to balance the demands of acting as a school with the need to deliver tourism products.

32 Although tourism is seen as a part of the schools' mission, the exact tourism strategy varies for each institution. The Spanish FREAAE has seen the most extensive touristification because it has been designed as a touristic site since its creation. The spatial organisation is mainly configured to welcome both students and tourists, and the school has long been associated with the creation of touristic activity - visits to 
museums and the palace. Today, it offers a wide range of activities every day in four languages from $10 \mathrm{am}$ to $2 \mathrm{pm}$ :

- full visit (stables, saddlery, arenas, gardens, palace, art museum, coaching museum) with shows from 12pm to 1.30pm - 1 to 3 times a week depending on the season;

- the show "Cómo Bailan los Caballos Andaluces" one Saturday per month (see illustration 1);

- short visit, without the show;

- visit to the coaching museum;

- private-hire options (weddings, seminars).

- outside galas in Spain or abroad, but only 1 to 2 per year.

Overall, 186,207 tourists visited the school in $2018^{7}$.

\section{Illustration 1}

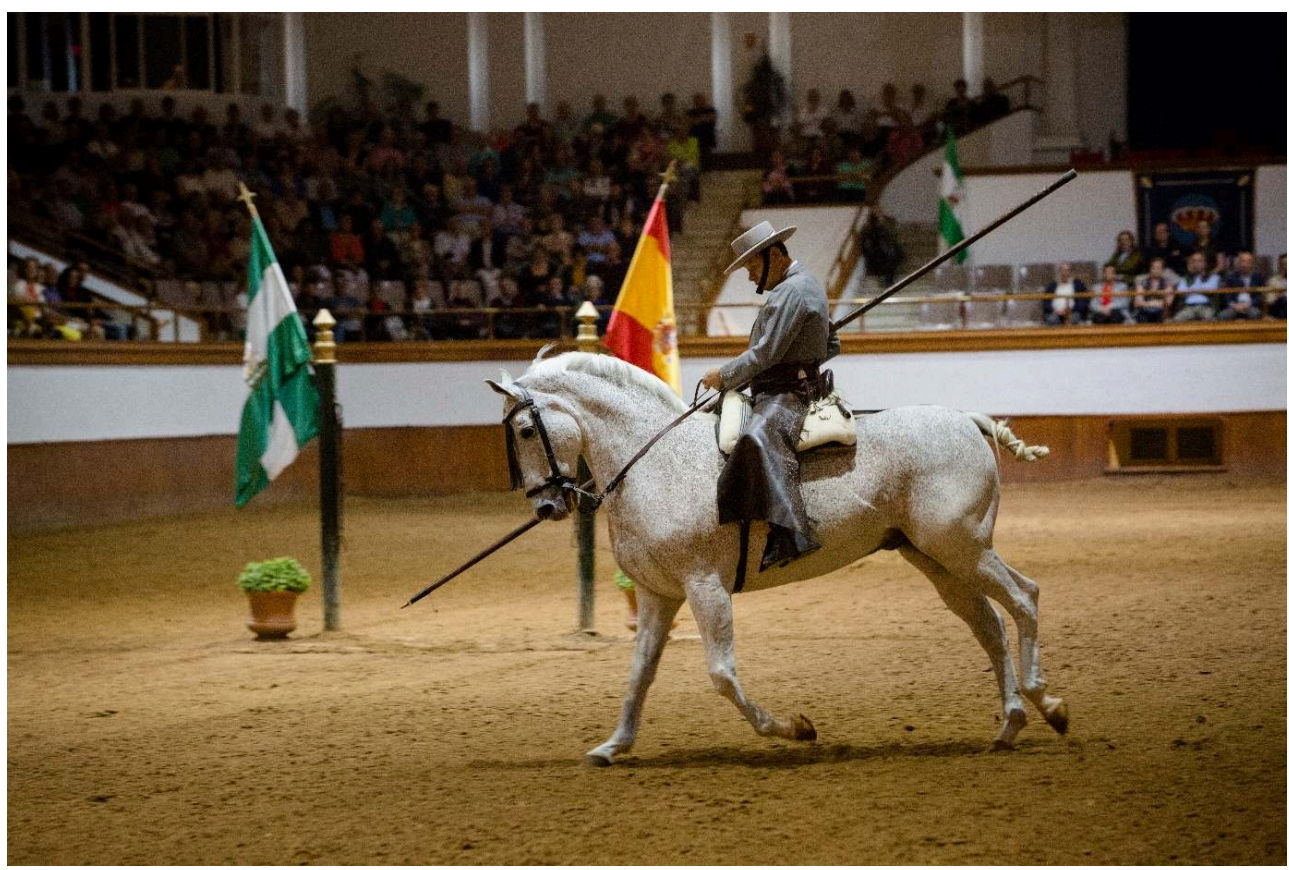

FREAAE, a school designed as a tourist and cultural site showing the traditional riding, here, doma vaquera. Saturday gala

FREAAE@2014

The French Cadre Noir, thanks to its double military (Cavalry School) and sporting $\left(\mathrm{ENE}^{8}\right)$ heritage, has been doubling as a tourism attraction since the founding of its civilian school, though only in a restricted way that saw tourists limited to spectating in the Grand Manège. It was only in the 2000s that the management pursued a more detailed tourism development strategy, with it becoming a necessity so as to favour a greater dissemination and also to boost cost-efficiency (Pickel-Chevalier, 2019). This has resulted in the creation of a department dedicated to tourism and a gift shop. The site has a cultural program operating during the tourist season, which was recently extended from 5 to 9 months per year [interview, FD]. It consists of public performances on the site on Thursday mornings (28 dates in 2018) and galas (10 dates in 2018 in situ and outdoors in France and abroad). In addition, they offer guided tours in four languages organised around different themes and depending on the audience (individuals; groups; young people; works council visits). In 2018, 94,425 visitors visited the school (2018). ${ }^{9}$ 

Portuguese EPAE was founded. Nonetheless, the tourism offer has been greatly strengthened since the institution's inclusion in the Sintra public enterprise. The school is open to visitors from 10a.m. to 1p.m. Tuesday to Saturday. The purchase of a tourist ticket includes a guided visit of the stables and the saddlery, available in three languages from 10am to 11am with the chance to see the horses being trained, followed by the public show in the grand Manège from $11.30 \mathrm{am}$ to $12.30 \mathrm{pm}$. The school also puts on a gala once a month on site, as well as 4 or 5 private events per year. The statistics are still modest $\left(7,062\right.$ in $\left.2018^{10}\right)$ but visitor numbers have been increasing [interview, DS].

Together, the three institutions are presented as touristified schools that intend to transmit equine heritage through a double diffusion to both students and visitors and at varying degrees. But tourism activity is not just a way of transmitting heritage: it also contributes to the process of constantly reinventing it. The following section will look at this aspect further.

\section{The co-construction of a holistic equestrian heritage}

Although the three schools testify to different styles of management, they are all dedicated to maintaining the equestrian culture of their country. This vision is shared from the managers down to the grooms, who all feel they are part of this scheme. ChL, groom at the Cadre Noir, stated: "We represent the tradition. I participate by taking care of the young horses. I teach them good behaviour based on patience, which is the French tradition recognised by UNESCO. It is not only about riding them" [interview]. In FREAAE, a groom also claimed: "My work also participates to the conservation of the Spanish culture, through the preparation of the equipment for the horses. I'm proud to contribute to the school's fame by doing so" [interview JJ].

In Jerez and Lisbon, the culture carefully combines national riding disciplines with selected national horse breeds. JQ, squire at the EPAE says: "Our objective must be to teach and maintain a tradition around Portuguese horses and Portuguese riding" [interview]. Likewise, at FREAAE, a student claimed: "The mission of the school is to conserve the Spanish tradition of equestrian art with Spanish horses. When I am older, I want to become a teacher to pass it on too" [interview, PS]. At the Cadre Noir, the use of an emblematic breed is less clearly stated, however $60 \%$ of the horses are Selle Français, indicating not an exclusive but a national preference. Furthermore, the French school allows mares and geldings while the other schools tend to focus on stallions.

This phenomenon demonstrates the relationship linking intangible and tangible heritage in each school, where the riding is associated to the husbandry of horses, through one (EPAE) or several national breeders (FREAAE, Le Cadre Noir). It is strengthened by the equipment that contributes to the identification of each tradition, with each school having specific costumes for the squires and unique tack for the horses, which includes characteristic plaits (braiding).

Thus, the schools promote a holistic equestrian heritage, where intangible (training and riding) and tangible (breed, costume, tack, plaits, architecture including stables) heritages feed each other (Seng, 2015). The result is a holistic equestrian heritage, one that tourism not only helps to transmit but also defines in turn. The emphasis of a heritage induces its identification by a choice of memory process (Babelon and Chastel, 
1995), since heritage is less inherited than socially constructed (Heinich, 2009; Hitchcock, King and Parnwell, 2010). Yet, this selection is co-constructed by the actors of the schools and by the tourists themselves who express, through their choice of visits, the social support essential to the recognition of a heritage value (Saupin, 2015). Tourism and heritage are, therefore, co-constituted (Lazzarotti, 2011).

The process has, nonetheless, not been the same in the three schools. In Jerez and Lisbon, it is the result of a conscious desire to recreate a partially lost heritage, one that includes a constructed historicity (Hartog, 2003). Therefore, their creators have chosen different periods from which to reinvent their national tradition (Hobsbawn, 2012a). The founders of EPAE have favoured the second half of the $18^{\text {th }}$ century, perceived as the "golden age" of Portuguese equestrian arts. This logic is outlined in the "Picaria Real' theorised by de Andrade, looking at the Alter Real horse, partially based at the Palais de Queluz (see illustration 2). Regarding the founders of the Jerez school, they forged their heritage around the association of the Haute Ecole (carousel, school jumps) and the bullfighting activities of the 18th and 19th centuries, illustrated in the movements of the doma vaquera. The role of tourism in this process of (re)invention of Portuguese and Spanish riding is obvious since both schools were created, in 1973 and 1979 respectively, with tourist presentations intended to embody their culture and identity: the Como Bailan los Caballos Andaluces show in Spain and the Picaria Real show in Portugal.

Illustration 2

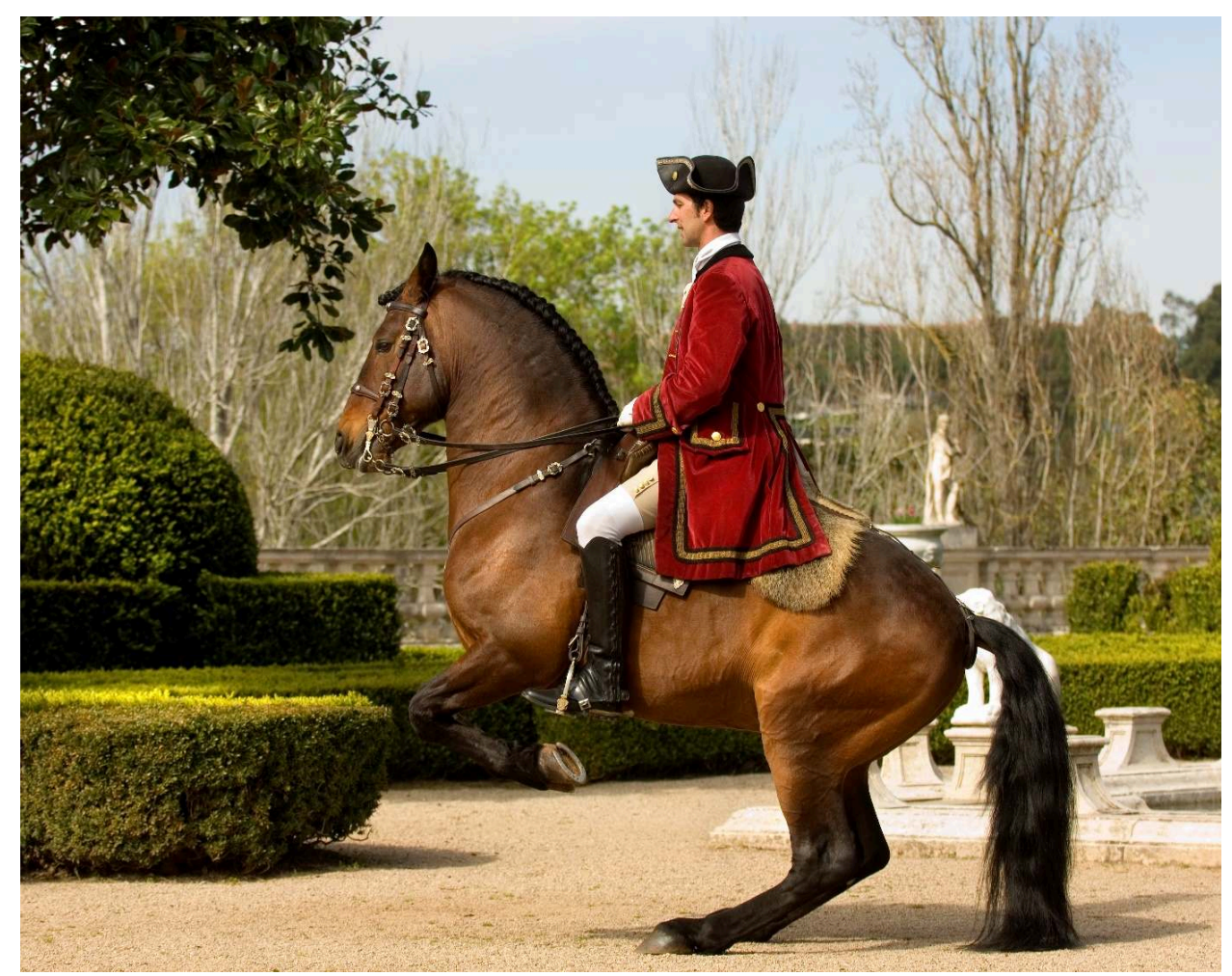

EPAE or the reinvention of the Picaria Real on Alter Real stallions EPAE@2012

The situation is more complex in Saumur. The heritagisation process is due to a change in the meaning of cultural objects (Pomian, 1987), as they lose their utilitarian function 
and develop a new function related to culture and heritage. Still, the Cavalry school, where the Cadre Noir was born, has survived from its origins through the $18^{\text {th }}$ century to the present day by combining conservation and an adaptation to arising new needs and responding to trends. Its heritagisation emanates from a more diffuse and less conscious dynamic, within an institution that continues to commit to the future. The school owes its on-going survival to a policy of sporting conversion, combined with shows, reaching back to 1828. If the Cadre Noir became a national and Republican icon during the Third Republic, the conceptualisation of "equitation in the French tradition" was confirmed decisively through the acquisition of UNESCO recognition in the $21^{\text {st }}$ century (Pickel-Chevalier, 2016). Although the designers defined this tradition through a combination of civilian and military heritage, insisting on lightness and harmony, the Cadre Noir shows sanctified its Belle Epoque style thereby crystallising the beginning of its legend (1896). This emphasised its modernisation - such as a move towards feminisation ${ }^{11}$ (see illustration 3) - and that is continuing nowadays in relation to competitions. In this context, it successfully combines the concepts of an 'Haute Ecole' with staged sporting performances including such acts as jumping tables, chairs and even pickets in artistic display.

Illustration 3

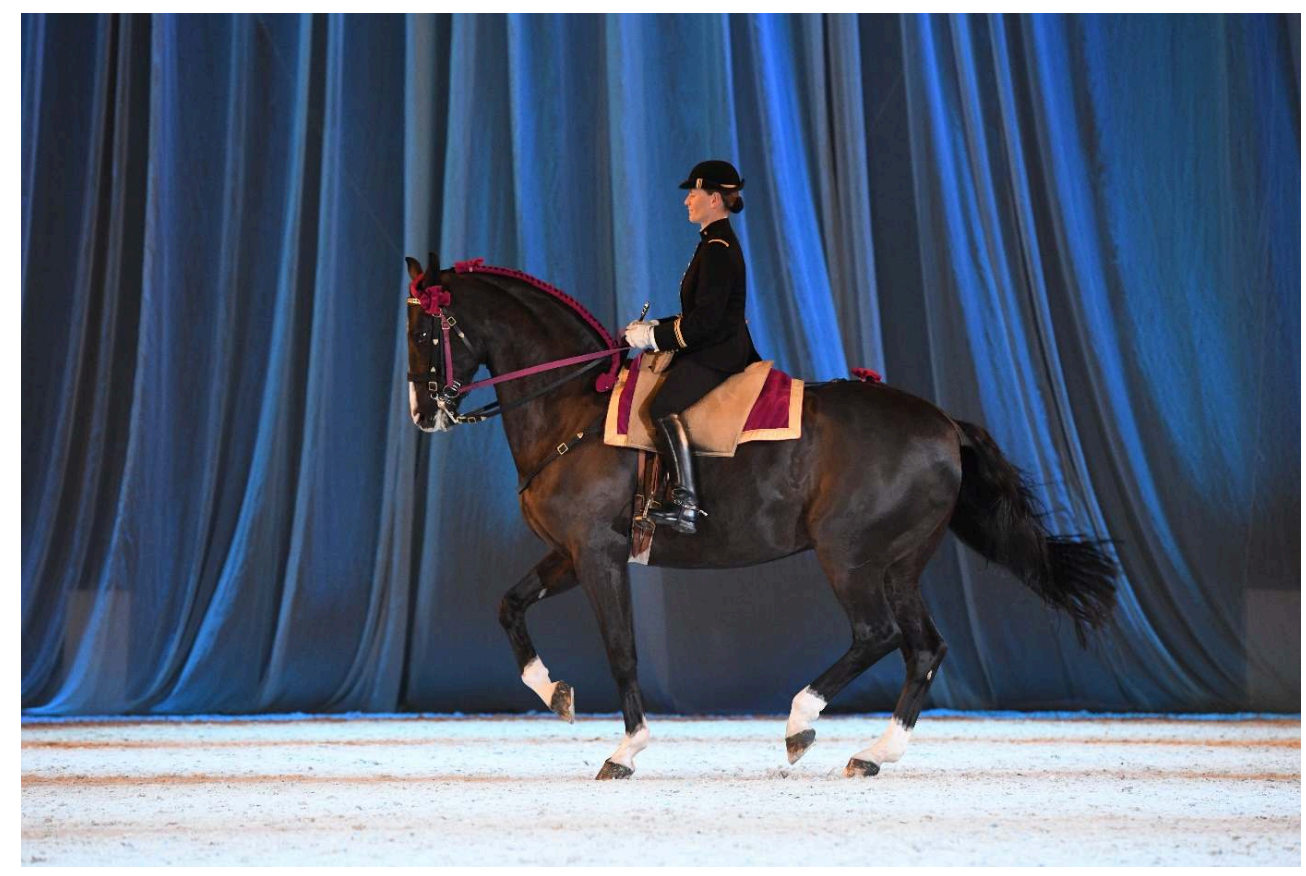

Riding in the French tradition at the Cadre Noir exhibition combines conservation of heritage, especially from the Belle Epoque, and modernisation elements such as feminisation

Alain Laurioux/Cadre noir IFCE 2019

Again, the role of tourism is important, especially since the registration for UNESCO intangible heritage requires transmission to a larger community, thus requiring distinctive visitor options. In return, tourists participate in the constant reinvention of the French tradition, especially through contemporary pressure from the animal-rights movement. "We insist now, in the exhibitions, but also in the communication medias such as posters and videos, on animal welfare, showing riders besides their horses, looking at them to insist on complicity and harmonious relations between them" 
explained the communication manager [interview FM]. This tourist influence on the evolution of equestrian traditions also characterises the Lisbon and Jerez schools, especially in their relationships with horses. "The tourists are most of time not riders themselves: they don't understand that we must discipline a young horse, so we need to reorganise our day work, to train the young horses before the visitors arrive at $10 \mathrm{~h}$, to show them only the experienced ones" explained a squire from EPAE [interview RV]. In addition, touristification also requires the renewal of exhibitions to favour visitor loyalty. This includes the introduction of shorter performances - with 8 horses for 15minute shows in Jerez and Lisbon - but also of new exhibitions combining the conservation of the schools' iconic figures and novelty. The chief squire at the Cadre Noir explained that in 2017 they created a new gala Au Coeur du Grand Manège, to meet tourists' expectations. He stated: "We wanted to renew the show, preserving the values and traditions of the Cadre Noir. We have worked on a presentation showing the daily work of the squires alongside a timeless scene - the Loire river. In addition, we highlight the emotion that the squires and the horses generate for the audience" [interview, PT]. All schools have developed specific protocols and habits in combing the training of their horses and riders with touristic consumption.

As such, tourist behaviour and representations contribute, even unconsciously, to the constant reinvention of equestrian traditions in the three schools by influencing both the training and the exhibitions.

\section{Conclusion}

This study demonstrates both the invented character of traditions (Hobsbawm, 2012) and the social construction of heritage (Babelon et Chastel, 1994; Heinich, 2009), echoing a constructed relationship with history (Pomian, 1987; Hartog, 2003) that contributes not only to transmitting, but also to the on-going redefinition of heritage and traditions through a combination of conservation, adaptation and innovation (Bortolotto, 2011). This co-creation is built on both a combination of memory selections by agents of tourism and heritage (Lazzarotti, 2011; Hitchcock, King et Parnwell, 2010; Richards, 2010; Wood, 1997), and also the choices of visitors who testify to social support in the recognition of a heritage value (Saupin, 2015). In this, the study also reveals the holistic characteristic of heritage, where tangible and intangible heritage are not simply opposed, but on the contrary, co-constructed (Seng, 2015).

As such, the three schools aim to perpetuate equine cultures, defined by a specific system of practices and representations linked to horses and shared by a community, around which they create an identity. They promote their legitimacy as a combination of both tangible and intangible heritage that feed each other. However, since heritage is more a construction than a historical transmission (Hobsbawm, 2012), it reflects, above all, choices of memory and reinvention of traditions, which can be official political constructions - Cadre Noir, EPAE - or more spontaneous social constructions, re-appropriated by institutions - FREAAE. Within the schools, these are illustrated by practices combining shared inheritances and national and regional characteristics, such as military riding in France, Gineta in Portugal and bullfighting in Spain, further accentuated by the morphological uniqueness of the horses which come from societal influences. 

(Hartog, 2003) from the $18^{\text {th }}$ century to the Belle Epoque and does not constitute a break from developments. On the contrary, the connection between conservation and innovation have defined the aspects of intangible heritage, ensuring the continuation of practices within contemporary society. In this context, education and competitions, as well as tourism, constitute vectors favouring the processes of reinvention by the ongoing adaptation to new sensibilities, expectations and the needs of the public. As such, for all three schools associate the strategy for conservation with a diffusion dynamic, characterised by two-fold distribution policies, aimed at a horse specialist community through training and at the larger community via engaging and entertaining tourism offers. Their dialogical relationship - the students training for tourists in particular and the tourists influencing both the organisation of the training and the exhibitions determines the co-constituted identity of the schools. Nonetheless, behind this common identification, through the combination of education and tourism, the exact expression of this policy differs between the three institution. The ENE was built in 1970 with priority given to its functionality for high-level education and training with restricted visitor access. Its repurposing as a tourist site, grafted onto an educational establishment, has therefore been complex and required considerable thought. It also included a strengthening of the institution's cultural development, which is currently underway, as evidenced by the forthcoming creation of a Culture Committee, joining the existing other four committees (Services, Breeding, Scientific, Employment \& Training) which together co-manage the IFCE.

Conversely, the FREAAE was specifically created as part of an overall cultural and tourism development strategy. It was therefore designed and equipped from its inception to welcome tourists with, for example, great care given to its infrastructure and aesthetics. Its tourist development has comparatively been more successful, though it needs to strengthen its schooling activities as both activities are fundamental to the overall success. The recent partnership project with a local university fits with this logic and seeks to build a string base for its internal education and training.

Lastly, the EPAE is currently in a process of reform, with the aim being to succeed in combining the functionality of training with tourist attractiveness. This development has been strengthened by its inclusion within the Sintra public company, whose role is to enhance heritage in the Lisbon region through its tourist and cultural development.

In summary, the schools express three different models of development in combining their goals of education and tourism with their individual strengths and limitations. Still, although they all have built significant imagery and reputations, their economic viability remains fragile. Like many cultural sites ${ }^{12}$, none of them can claim to be a selffunding institution: in 2018, the Cadre Noir covered $31 \%^{13}$ of its costs through selffinancing, the FREAAE 28.5\% [interview JG] and the EPEA $13.4 \%{ }^{14}$. Thus, even if the number of visitors would increase at each site, they all need better regional integration, which requires the establishment of multi-scale connections with a range of political and socio-economic actors. Such cluster networks could include further European projects through the creation of partnerships between further traditional riding schools, to together promote European equine cultures while acknowledging their differences. The process of heritage registration, putting Portuguese and Spanish classical riding on the UNESCO list, could help fulfil this ambition, reinforcing international recognition - as it did for Equitation in the French tradition - and most of 
all, local community cohesion. Registration has been seen to aid in the assimilation of a heritage within a community (Bortolotto, 2011) through the redefinition in present time that it promotes (Tornatore, 2019). The study of classical schools of equitation illustrates the "presentism" of heritage (Hartog, 2002), a living interpretation of the past in the terms of current society. It also demonstrates the fundamental role of tourism as a catalyst for this process (Lazzarotti, 2011; Wood, 1997), inducing the double phenomena of selecting and casting new light on memory - combining preservation, adaptation, and perpetual reinvention, in a changing world.

\section{BIBLIOGRAPHY}

Teresa ABRANTES, Portuguese school of Equestrian Art, Parques de Sintra, 2014.

Miriam ADELMAN and Jorge KNIJNIK, Gender and Equestrian Sport, Springer, 2013.

Juan Carlos altamirano, Real Escueal Andaluza Del Arte Ecuestre, Junta Andalouzia, 2007.

LC AUBLET, L'école de Cavalerie de Saumur, Éditions du Centaure, 1953.

Jean- Pierre BABELON and André CHASTEL, La notion de patrimoine, Liana-Levi, 1994.

Chiara BoRTOLOTTO, Le patrimoine culturel immatériel, Maisons des sciences de l'homme, 2011.

Pierre BOURDIEU, Choses dites, Minuit, 1987.

Jean-Pierre DIGARD, Une histoire du cheval, Actes Sud, 2007.

Guy DI MEO, “Une géographie sociale”, Cybergéo, 2016 [http://journals.openedition.org/cybergeo/ 27761].

Rodney HARRISON, Heritage: critical approaches, Routledge, 2013.

François HARTOG, Régimes d'historicité. Présentisme et expérience du temps, Le Seuil, 2003.

Nathalie HEINICH, La fabrique du patrimoine. De la cathédrale à la petite cuillère, Maison des sciences de l'homme, 2009.

Guillaume HENRY and Marine OUSSEDIK, Une histoire de l'équitation française, Belin, 2014.

Michael HIтснсоск, Victor KING and Michael PARNwell (eds.), Heritage Tourism in Southeast Asia, Nias Press, 2010.

Eric HOBSBAWM, "Introduction: inventing traditions", in Eric HOBSBAWN and Terence RANGER (eds.), The invention of tradition, Cambridge University Press, 2012a.

Eric HOBSBAWM, “Mass-producing traditions: Europe, 1870-1914”, in Eric HOBSBAWN and Terence RANGER, op. cit., 2012 b.

Olivier LAZZAROTTI, Tourisme et patrimoine, Belin, 2011.

Olivier LAZZAROTTI « Patrimoine », dans Jacques LÉVY and Michel LuSSAULT, Dictionnaire de la géographie et de l'espace des sociétés, Belin, 2013. 
Michel LuSSAult, “Constructivisme”, in Jacques Lévy and Michel Lussault, Dictionnaire de la géographie et de l'espace des sociétés, Belin, 2013.

Pierre PAILLÉ and Alex MUCCHIELLI, L'analyse qualitative en sciences humaines et sociales, Armand Colin, 2008.

Sylvine PICKEL-CHEVALIER, "Tourism and Equine Heritage in France: the case study of the Cadre noir de Saumur and the Vendée Stud", Current Issues in Tourism, 2019 [doi.org/

$10.1080 / 13683500.2019 .1706459]$.

Sylvine PICKEL-CHEVALIER, "Popular Horse Stories and the Invention of the Contemporary HumanHorse Relationship through an 'Alter Ego' paradigm", Journal of Sports Science, vol. 5, 2017a.

Sylvine PICKEL-CHEVALIER, "L'équitation française et sa patrimonialisation dans la société des loisirs”, EspacesTemps.net, 2016 [https://www.espacestemps.net/articles/lequitation-francaise-etsa-patrimonialisation-dans-la-societe-des-loisirs/].

Krzysztof POMIAN, Collectionneurs, amateurs et curieux, Gallimard, 1987.

Greg RICHARDS, "Tourism and the World of Culture and Heritage", Tourism Recreation Research, vol. 25 , no. $1,2000$.

Daniel Roche, La culture équestre de l'Occident. T1. Le cheval moteur, Fayard, 2008.

Daniel RocHE, La culture équestre de l'Occident. T2. La puissance et la gloire, Fayard, 2011.

Guy SAUPIN, "Les nouveaux patrimoines culturels au regard des sciences humaines et sociales", in Jean-René MORICE, Guy SAUPIN and Nadine VIVIER (eds.), Mutations de la culture patrimoniale, Presses universitaires de Rennes, 2015.

Eva-Maria SENG, "Patrimoine culturel immatériel : plaidoyer pour une vision globale du patrimoine culturel" in Jean-René MORICE, Guy SAUPIN and Nadine VIVIER, op. cit.

Catherine TOURRE-MALEN, "Évolution des activités équestres et changement social en France à partir des années 1960", Le mouvement social, no. 229, 2009.

Robert WOOD, "Tourism and the state: Ethnic options and constructions of otherness", in Michel PICARD and Robert WOOD (eds.), Tourism, ethnicity and the State in Asian and pacific societies, University of Hawaii Press, 1997.

Jean-Louis TORNATORE, Le patrimoine comme expérience, Maison des sciences de l'homme, 2019.

Robert YIN, Case study research and applications. Design and methods ( $6^{\text {th }}$ ed.), Sage, 2018.

\section{NOTES}

1. Faro convention, 2005, https://www.coe.int/en/web/conventions/full-list/-/conventions/ rms/0900001680083746

2. https://ich.unesco.org/en/convention\#art2

3. According to Harrison (2013), "heritagization" defines a process in which objects, places and practices are turned into heritage as cultural significance is attached to them.

4. Les écoles de Cavalerie: l'équitation en France, published in 1896 by the Baron de Vaux, is the first official text using the "Cadre Noir" to present the school's squires.

5. Péguy C., L'Argent, $6^{\mathrm{e}}$ Cahier de la Quinzaine de la $14^{\mathrm{e}}$ série, 16 février 1913.

6. https://ich.unesco.org/fr/RL/lequitation-de-tradition-francaise-00440

7. FREAAE annual report, 2019. 
8. The ENE appellation disappeared in 2010, with the school taking the name of the squires: Le Cadre noir de Saumur.

9. IFCE/Le Cadre Noir annual report, 2019.

10. EPAE annual report, 2019.

11. Feminisation exists in the two other schools more restrictively: 1 squire in the FREAAE and 2 trainees squires in the EPAE.

12. A study carried out in 2018 by the French National Assembly looking at 24 cultural sites revealed an average self-financing rate of $27 \%$.

13. IFCE/Le Cadre Noir annual report, 2019.

14. EPEA annual report, 2019.

\section{ABSTRACTS}

Europe is a melting pot of equestrian traditions, combining national characteristics with a common heritage. However, science and technical progress weakened the centuries-old use of horses in the $20^{\text {th }}$ century. They survived modernity by being re-codified as a source of sport and leisure in an emerging consumer society. Faced with such changes, the question of the survival of classical riding traditions arises. Different public schools in Europe intend on maintaining these traditions. To do so, they must demonstrate their capacity to transmit ideas of classical riding to a large community, addressing both specialists and the general public. In this context, they have taken the initiative of combining the training of students and tourism activities. The objective of my study is to assess their capacity to conserve the intangible heritage of classical riding in modern society, through this double strategy of transmission, focusing especially on: the Cadre Noir de Saumur in France; the Real Escuela Andaluza del Arte Ecuestre of Jerez de la Frontera in Spain and the Escola Portuguesa de Arte Equestre of Lisbon in Portugal. In doing so I will elaborate on the construction of intangible heritage, including the (re)invention of traditions, and the role of tourism in this process. My methodology is based on a structuralist constructivism approach, combining literature review, statistical studies, qualitative observations conducted at the three sites and qualitative interviews with 48 people involved at different levels in the conservation of local equestrian heritage, conducted between February 2019 and January 2020.

L'Europe constitue un creuset de traditions équestres, combinant particularismes nationaux et patrimoines communs. Les progrès des sciences et techniques ont néanmoins fragilisé l'utilisation pluri-centenaire du cheval $\mathrm{au} \mathrm{xx}^{\mathrm{e}}$ siècle. Il a survécu à la modernité grâce à sa recodification dans les sphères du sport et du loisir au sein de la société de consommation. Face à de telles évolutions, se pose la question de la perpétuation des équitations de tradition. Différentes écoles publiques en Europe s'efforcent de conserver ces patrimoines. Pour ce faire, elles doivent parvenir à transmettre les équitations classiques à une communauté élargie, combinant spécialistes et grand public. Dans ce contexte, elles associent formation des étudiants et activités touristiques. Le dessein de mon étude est de questionner la capacité de ces écoles à conserver le patrimoine immatériel des équitations de tradition dans la société contemporaine, au travers de cette double stratégie de transmission, en me focalisant plus particulièrement sur : le Cadre noir de Saumur, la Real Escuela Andaluza del Arte Ecuestre de Jerez de la Frontera en Espagne et la Escola Portuguesa de Arte Equestre de Lisbonne au Portugal. Elle interroge la 
construction du patrimoine immatériel, incluant la réinvention des traditions et le rôle du tourisme dans ce processus. Ma méthodologie repose sur une approche structuraliste constructiviste, combinant revue de la littérature, analyses statistiques, observations qualitatives sur les trois sites et étude qualitative menée entre février 2019 et janvier 2020 auprès de 48 personnes investies à différents niveaux dans la conservation des patrimoines équestres locaux.

\section{INDEX}

Mots-clés: patrimoines équins, écoles européennes d'équitation de tradition, Saumur, Jerez, Lisbonne

Keywords: equine heritage, European classical riding schools, Saumur, Jerez, Lisbon

\section{AUTHOR}

\section{SYLVINE PICKEL-CHEVALIER}

Associate Professor

Research Director in Geography (HDR)

ESTHUA University of Angers

UMR CNRS 6590 Spaces and Societies

Sylvine.chevalier[at]univ-angers.fr 